Tropical Journal of Pharmaceutical Research September 2020; 19 (9): 1993-1998

ISSN: $1596-5996$ (print); 1596-9827 (electronic) (C) Pharmacotherapy Group, Faculty of Pharmacy, University of Benin, Benin City, 300001 Nigeria.

\title{
Methyl 4-( $\beta$-D-glucopyranosyloxy)-3-hydroxy-5- methoxybenzoate, isolated from Sanguisorba officinalis, inhibits CpG-DNA-induced inflammation
}

\author{
Mohammad Saydur Rahman ${ }^{1}$, Irshad Ali ${ }^{1}$, Madeeha Arooj ${ }^{1}$, Xiang Dong Su², \\ Seo Young Yang ${ }^{2}$, Young Ho Kim², Young-Sang Koh ${ }^{1 *}$ \\ ${ }^{1}$ Department of Microbiology and Immunology, School of Medicine and Brain Korea 21 PLUS Program, and Jeju Research \\ Center for Natural Medicine, Jeju National University, Jeju, ${ }^{2}$ College of Pharmacy, Chungnam National University, Daejon \\ 34134, South Korea
}

*For correspondence: Email: yskoh7@jejunu.ac.kr; Tel: +82-64-754-3851; Fax: +82-64-702-2687

\begin{abstract}
Purpose: To evaluate the anti-inflammatory effect of methyl-4-( $\beta$ - $D$-glucopyranosyloxy)-3-hydroxy-5methoxybenzoate (comp-1) on immune cells.

Methods: Comp-1 was isolated from Sanguisorba officinalis. After treating with comp-1, cell viability and levels of pro-inflammatory cytokines were assessed utilizing MTT assay and ELISA, respectively. Besides, the effects of comp-1 on nuclear factor kappa $B$ (NF-KB), mitogen-activated protein kinase (MAPK), and iNOS were determined using western blotting. Moreover, nitric oxide production was assessed using the Griess reagent.

Results: Treatment of dendritic cells (DCs) with CpG DNA upregulated cytokine expression. Comp-1 markedly downregulated the expressions of IL-12 p40, IL-6, and TNF- $\alpha$, with $50 \%$ inhibitory concentrations $\left(I C_{50}\right)$ of $1.077 \pm 0.04(p<0.01), 0.28 \pm 0.01(p<0.01)$, and $0.79 \pm 0.02 \mu M(p<0.01)$, respectively. Treatment of DCs with CpG DNA upregulated NF-KB and MAPK activation. However, pretreatment of the cells with Comp-1 suppressed CpG DNA-induced NF-KB and MAPK activation. Moreover, comp-1 exhibited a strong anti-inflammatory effect by inhibiting nitric oxide production and iNOS expression.

Conclusion: These results reveal that comp-1 has significant anti-inflammatory effect on immune cells.

Keywords: Natural compound, Inflammation, Pro-inflammatory cytokine, Toll-like receptor9

This is an Open Access article that uses a fund-ing model which does not charge readers or their institutions for access and distributed under the terms of the Creative Commons Attribution License (http://creativecommons.org/licenses/by/4.0) and the Budapest Open Access Initiative (http://www.budapestopenaccessinitiative.org/read), which permit unrestricted use, distribution, and reproduction in any medium, provided the original work is properly credited.

Tropical Journal of Pharmaceutical Research is indexed by Science Citation Index (SciSearch), Scopus, International Pharmaceutical Abstract, Chemical Abstracts, Embase, Index Copernicus, EBSCO, African Index Medicus, JournalSeek, Journal Citation Reports/Science Edition, Directory of Open Access Journals (DOAJ), African Journal Online, Bioline International, Open-J-Gate and Pharmacy Abstracts
\end{abstract}

\section{INTRODUCTION}

Inflammatory responses are developed as a response to infections caused by different microorganisms [1]. Toll-like receptors (TLRs) are important receptors which play vital roles in immune responses [2]. Dendritic cells (DCs) are the highly efficient antigen presenting cells which participate in the fight against various microorganisms [3]. TLR stimulation is responsible for nuclear factor kappa B (NF-kB) and mitogen-activated protein kinase (MAPK) activation, leading to produce pro-inflammatory mediators $[1,4,5]$. 
MAPKs play versatile roles in controlling differentiation, proliferation, growth, and apoptosis. In inflammatory pathways, pathogenassociated molecular patterns bind to TLRs. Thus, the activated MAPK pathways transmit signals from the cell surface receptor to the nucleus [6]. Inflammatory pathways activate extracellular signal-regulated kinases (ERKs), cJun N-terminal kinases (JNKs), and p38 MAPKs [7]. ERKs play an essential part in innate immunity via cytokines expression [8]. JNKs play an essential role in stress signaling pathways and regulate different cellular and physiological events [9]. p38 is an important MAPK pathway involved in the regulation of different cellular activities like inflammation, differentiation, apoptosis and autophagy [10].

The mammalian NF-KB signaling pathway is a well-studied inflammatory and - pathway, which is activated by $1 \mathrm{KBa}$ phosphorylation and its subsequent degradation [11].

Unmethylated CpG DNA derived from bacteria and viruses is a tested ligand for TLR9 [1]. Stimulating immune cells with CpG DNA initiates the pro-inflammatory signaling cascade, leading to cytokines production [12].

Nitric oxide not only has anti-microbial activities, but also damages host tissues and is responsible for the development of inflammatory diseases [13]. iNOS is an important enzyme involved in nitric oxide production from L-arginine [14].

Sanguisorba officinalis $L$ is a renowned medicinal plant. Methyl-4-( $\beta$-D-glucopyranosyloxy)-3hydroxy-5-methoxybenzoate (comp-1) is one of the compounds extracted from $S$. officinalis [15]. The present investigation aimed to determine the anti-inflammatory effect of comp-1. a)

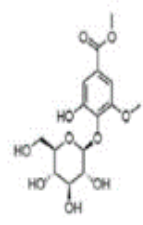

b)

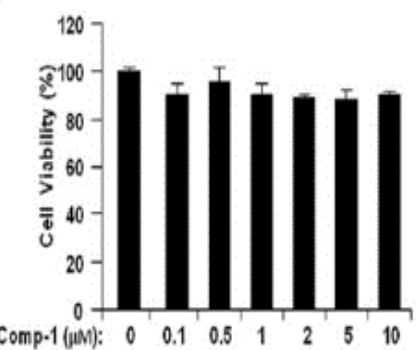

Figure 1: (a) Chemical structure of comp-1. (b) Dendritic cells (DCs) showed no cytotoxicity after treatment with different comp-1 doses $(0.1,0.5,1,2,5$ and $10 \mu \mathrm{M}$ ) for $24 \mathrm{~h}$ as shown by the cell viability that was estimated using the MTT assay.

\section{EXPERIMENTAL}

\section{Mice}

All experiments were authenticated and conducted following the instructions of the Institutional Animal Care and Use Committee of Jeju National University (Approval no.; 20160059, 28 December 2016). All procedures were conducted according to international guidelines as well [16].

\section{Cell cultures}

According to previously described method [17], DCs were grown in RPMI 1640 medium supplementing with $10 \%$ FBS, $3 \%$ GM-CSF, $0.1 \%$ of $\beta$-mercaptoethanol and $1 \%$ PG/SM. The cells were incubated at $37{ }^{\circ} \mathrm{C}$ in a $5 \% \mathrm{CO}_{2}$ environment.

\section{Cell viability assay}

DCs $\left(2 \times 10^{5}\right.$ cells $\left./ \mathrm{mL}\right)$ were pre-treated with comp-1 for $24 \mathrm{~h}$. Thereafter, DCs were incubated with MTT solution for $4 \mathrm{~h}$, and centrifuged. After discarding the supernatants, the formazan crystals produced were dissolved in DMSO (250 $\mu \mathrm{L})$. Then the absorbance was assessed at 540 $\mathrm{nm}\left(A_{540}\right)$.

\section{Measurement of cytokine production}

DCs were treated with comp-1 and then stimulated for $24 \mathrm{~h}$ with CpG DNA. The supernatant was collected and production of cytokine was assessed utilizing ELISA.

\section{Nitric oxide production}

Nitric oxide production was evaluated with the Griess reagent. RAW264.7 cells $\left(2 \times 10^{5}\right.$ cells $\left./ \mathrm{mL}\right)$ were first incubated in the presence of comp-1 for $1 \mathrm{~h}$ and then with CpG DNA for $24 \mathrm{~h}$. Then, the supernatant was collected and nitrite production was measured by assessing at $A_{540}$ after treating with the Griess reagent.

\section{Western blot analysis}

Briefly, before stimulation with CpG DNA at different time intervals, DCs were treated with or without $10 \mu \mathrm{M}$ of comp-1. Whole-cell lysate was extracted with a lysis buffer. Protein samples were electrophoresed on SDS-polyacrylamide gel and electrotransferred to a polyvinylidene fluoride membrane. Each membrane was incubated with specific primary antibodies for phospho-ERK, ERK, phospho-JNK, JNK, phospho-p38, p38, phospho- IKBa, IKBa, iNOS 
and $\beta$-actin. Immunoreactive bands were analyzed according to the previously described procedure [18].

\section{Statistical analysis}

Data are shown as mean \pm SD. Comparison of results between the comp-1-treated groups and controls were analyzed using One-way ANOVA. The SPSS version 16 software was used for the statistical procedure. Statistical significance was considered at $p<0.05$.

\section{RESULTS}

\section{Comp-1 showed no cytotoxicity in DCs}

The chemical structure of comp-1 is shown (Figure $1 \mathrm{a}$ ). To evaluate the in vitro cytotoxicity of comp-1, DCs were incubated for $24 \mathrm{~h}$ with the mentioned comp-1 doses, and cell viability was estimated using the MTT assay. This result revealed that comp-1 concentrations used in the present investigation did not affect cell viability (Figure $1 \mathrm{~b}$ ).

\section{Effect of comp-1 on CpG DNA-induced expressions of pro-inflammatory cytokines}

The cytokine levels in DCs increased upon CpG DNA stimulation. On the contrary, pre-treatment with comp-1 significantly reduced IL-12 p40, IL-6, and TNF- $\alpha$ levels, its $50 \%$ inhibitory concentration $\left(\mathrm{IC}_{50}\right)$ being $1.077 \pm 0.04,0.28 \pm$ 0.01 and $0.79 \pm 0.02 \mu \mathrm{M}$, respectively (Figure 2). The results reveal that comp-1 inhibited the expression of pro-inflammatory cytokines.

\section{Comp-1 inhibits the MAPK signaling pathway}

The effects of comp-1 on CpG DNA-induced MAPK phosphorylation in DCs treated with or without comp-1 were analyzed using western blot assay (Figures 3a and b). All three MAPKs were phosphorylated between 15 to $30 \mathrm{~min}$ and returned to basal level within $60 \mathrm{~min}$ in $\mathrm{CpG}$ DNA-treated DCs. However, comp-1 treatment significantly inhibited MAPK phosphorylation in CpG DNA-treated DCs (Figures $3 a$ and b).

\section{Comp-1 inhibits the NF-kB signaling pathway}

Phosphorylation and degradation of IKBa were observed between 15 to 30 min but returned to basal levels within $60 \mathrm{~min}$ of stimulation with CpG DNA (Figures $4 a$ and b). Treatment with comp-1 inhibited phosphorylation and degradation of $1 \mathrm{kB \alpha}$ in CpG DNA-treated DCs (Figures $4 \mathrm{a}$ and $\mathrm{b}$ ). Therefore, these findings indicate that comp-1 significantly blocked NF-KB activation.
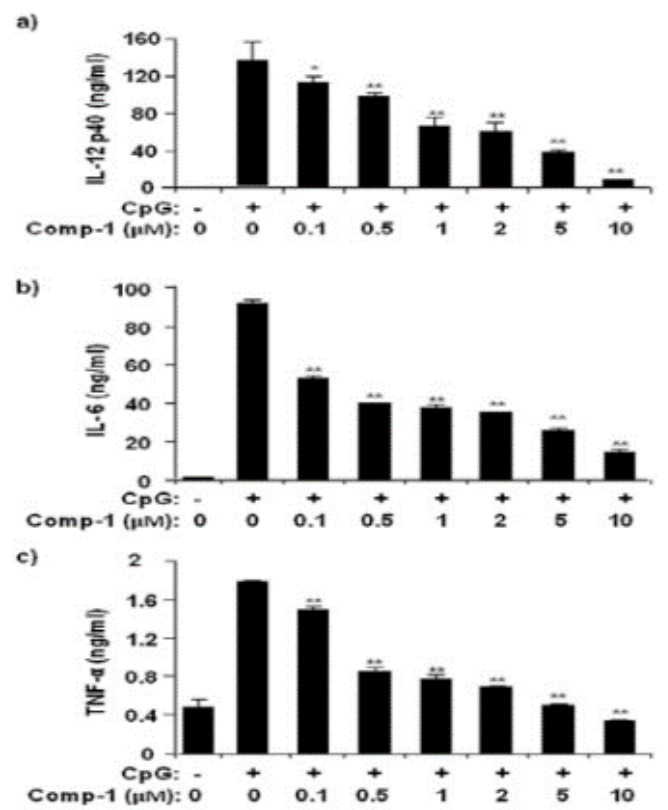

Figure 2: Effect of comp-1 on cytokine expression (ac): After treatment of DCs with comp-1 and CpG DNA, culture media were assayed by ELISA to determine the expression levels of (a) IL-12 p40, (b) IL-6, and (c) TNF- $\alpha$; ${ }^{*} p<0.05,{ }^{* *} p<0.01$ vs. comp-1-untreated and CpG DNA-treated DCs

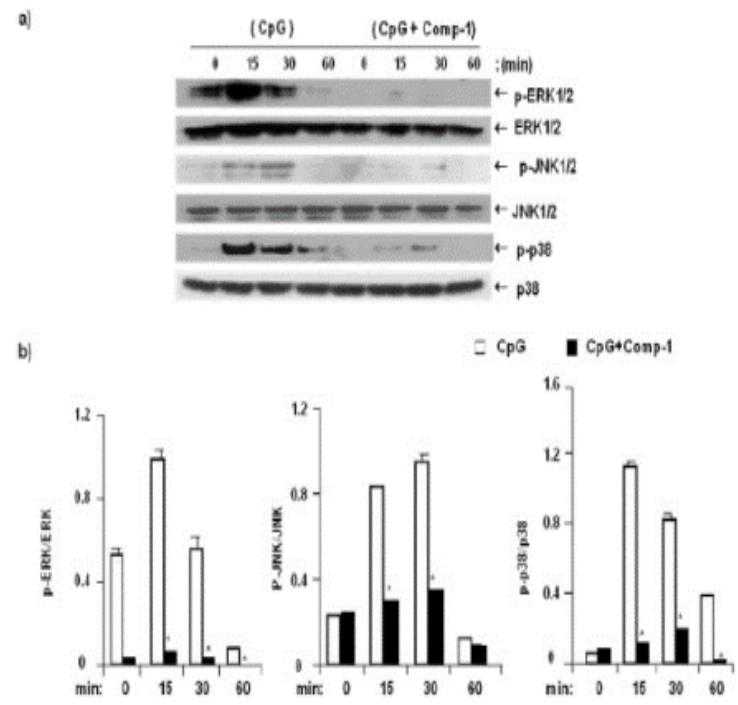

Figure 3: Effect of comp-1 on MAPK phosphorylation in CpG DNA-treated DCs. (a) DCs were incubated with or without $10 \mu \mathrm{M}$ of comp-1, and further treated with $1 \mu \mathrm{M}$ CpG DNA. The whole-cell lysates were collected at the given time periods and protein phosphorylation was determined by western blotting. (b) Scanning densitometry was utilized for quantifying the phosphorylated MAPKs; ${ }^{*} p<0.05$ vs. comp-1untreated and CpG DNA-treated DCs

Trop J Pharm Res, September 2020; 19(9): 1995 


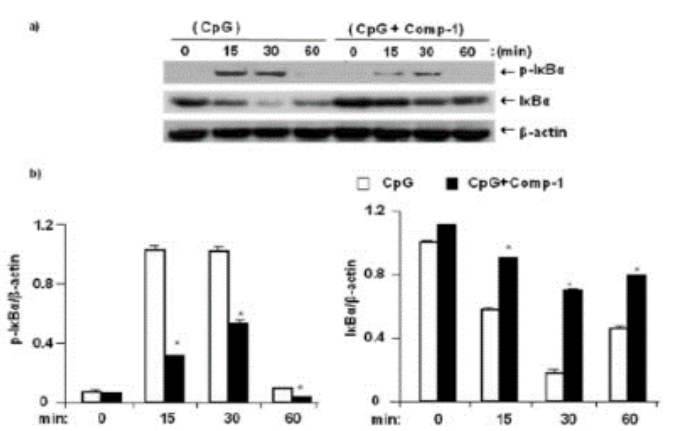

Figure 4: Effect of comp-1 on NF-kB activation. (a) DCs were incubated with or without $10 \mu \mathrm{M}$ comp-1 before $1 \mu \mathrm{M}$ CpG DNA-stimulation. The whole-cell lysates were extracted at the given time intervals. IKBa phosphorylation and degradation were measured with respect to those of $\beta$-actin by western blotting. (b) Scanning densitometry was used to quantify IKBa phosphorylation and degradation; ${ }^{*} p<0.05$ vs. comp1-untreated and CpG DNA-treated DCs

\section{Comp-1 inhibits NO and iNOS production}

RAW264.7 cells were incubated with indicated doses of comp-1, then stimulated with CpG DNA, and nitric oxide release was estimated. Comp-1 pre-treatment decreased nitric oxide production dose-dependently (Figure 5a). Western blot analysis was carried out for the measurement of iNOS expression, CpG DNA treatment led to increased iNOS expression, while comp-1 treatment significantly reduced the iNOS levels $(p<0.01$, Figures $5 b$ and $c)$. These experimental data show that comp-1 inhibited the production of $\mathrm{NO}$ and iNOS.

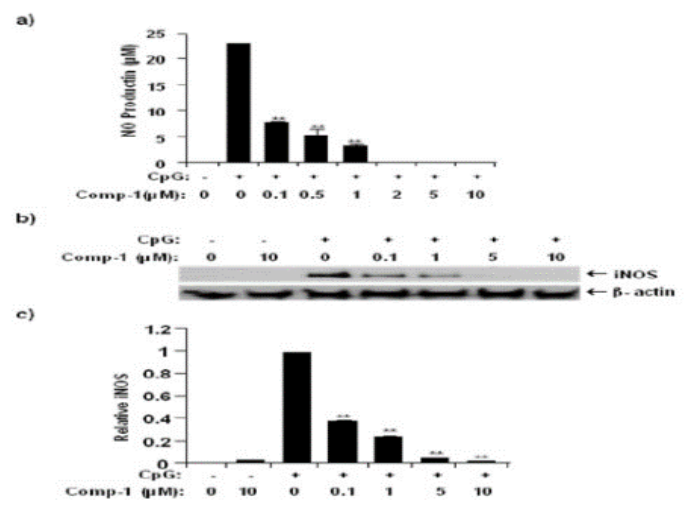

Figure 5: Effect of comp-1 on the production of NO and iNOS. Before induction with $1 \mu \mathrm{M}$ CpG DNA, RAW264.7 cells were incubated with the given doses of comp-1 for $1 \mathrm{~h}$. (a) NO production was evaluated with the Griess assay. (b) The expression levels of iNOS were measured with respect to those of $\beta$-actin using western blotting. (c) Scanning densitometry was used to quantify iNOS expression, which was normalized with the control protein; ${ }^{*} p<0.05$, ${ }^{* *} p<$ 0.01 vs. comp-1-untreated and CpG DNA-treated cells

\section{DISCUSSION}

The present study illustrates that comp-1 is capable of inhibiting CpG DNA-stimulated inflammation. It also shows that comp-1 has the capability to suppress NF-KB and MAPKs signaling and inhibit production of $\mathrm{NO}$ and iNOS expression.

Pro-inflammatory cytokines are mainly expressed by activated DCs and play important roles in immune response [1]. IL-12 p40 plays a vital role in autoimmune response mediated by Th1 lymphocytes. Therefore, the reduction in IL-12 p40 production might be beneficial against autoimmune diseases [19]. IL-6 affects physiological processes, such as hematopoiesis, control of cell growth, inflammation, proliferation, and differentiation [20]. Treatment with comp-1 reduces IL-6 production in CpG DNA-induced DCs dose-dependently. Therefore, the attenuation of IL- 6 expression by comp- 1 may be helpful for developing anti-inflammatory drugs. TNF- $\alpha$ overexpression is responsible for autoimmune diseases like Crohn's disease and rheumatoid arthritis [21]. The present investigation shows that comp- 1 has the potential to treat TNF- $\alpha$-related diseases. The experimental data revealed that comp-1 inhibits cytokine production dose-dependently. Therefore, further studies focusing on the effectiveness of comp-1 in inflammatory diseases should be conducted.

CpG DNA-stimulated TLR9 activates NF-KB as well as MAPKs signaling pathways, and ultimately produce inflammatory mediators [22]. In the present investigation, MAPK phosphorylation was significantly blocked in CpG DNA-induced DCs by comp-1 treatment. Comp-1 also significantly downregulated NF-KB activation. This study reveals that comp- 1 inhibits the activation of NF-KB and MAPKs signaling.

Nitric oxide regulates inflammatory responses. The cytotoxic effect of nitric oxide enables it to fight against pathogenic microorganisms. Nitric oxide also has the ability to produce reactive nitrogen species that can alter diverse cellular activities. Activated inflammatory cells produce iNOS, which catalyzes nitric oxide synthesis [13]. The present study revealed that comp-1 significantly reduced the levels of production of nitric oxide and inhibited iNOS expression.

Activated NF-KB and MAPKs participate in the transcription of different pro-inflammatory cytokines and inflammatory mediators [23]. The present research suggests that suppressive effects of comp-1 on the productions of 
inflammatory cytokines, NO, and iNOS, are associated with the blockage of NF-kB and MAPKs signaling mediated by TLR9. Consequently, the anti-inflammatory properties of comp-1 might be effective in inflammatory diseases.

\section{CONCLUSION}

The findings of this study show that comp-1 inhibits the production of pro-inflammatory cytokines, which are linked to the blockage of NF-KB and MAPKs cellular signaling pathways. This compound also inhibits NO production by decreasing iNOS expression. Thus, comp-1 might be a strong drug candidate for treating inflammation as well as autoimmune diseases.

\section{DECLARATIONS}

\section{Acknowledgement}

This work was supported by a research grant from Chuongbong Academic Research Fund of Jeju National University, Korea in 2018.

\section{Conflict of interest}

No conflict of interest is associated with this work.

\section{Contribution of authors}

We declare that this work was done by the authors named in this article and all liabilities pertaining to claims relating to the content of this article will be borne by the authors.

\section{Open Access}

This is an Open Access article that uses a funding model which does not charge readers or their institutions for access and distributed under the terms of the Creative Commons Attribution License (http://creativecommons.org/licenses/by/ 4.0) and the Budapest Open Access Initiative (http://www.budapestopenaccessinitiative.org/rea d), which permit unrestricted use, distribution, and reproduction in any medium, provided the original work is properly credited.

\section{REFERENCES}

1. Takeuchi O, Akira S. Pattern recognition receptors and inflammation. Cell 2010; 140(6): 805-820.

2. Roach JC, Glusman G, Rowen L, Kaur A, Purcell MK, Smith KD, Hood LE, Aderem A. The evolution of vertebrate toll-like receptors. Proc Natl Acad Sci USA 2005; 102(27): 9577-9582.

3. Efron PA, Tsujimoto $H$, BahjatFR, Ungaro $R$, Debernardis J, Tannahill C, Baker HV, Edwards CK, Moldawer LL. Differential maturation of murine bone-marrow derived dendritic cells with lipopolysaccharide and tumor necrosis factor-alpha. J Endotoxin Res 2005; 11(3): 145-160.

4. Medzhitov R. Toll-like receptors and innate immunity. Nat Rev Immunol 2001; 1(2): 135-145.

5. Akira S, Takeda K. Toll-like receptor signalling. Nat Rev Immunol 2004; 4(7): 499-511.

6. Chen Z, Gibson TB, Robinson F, Silvestro L, Pearson G, Xu B, Wright A, Vanderbilt C, Cobb MH. MAP kinases. Chem Rev 2001; 101(8): 2449-2476.

7. Hommes DW, Peppelenbosch MP, Van Deventer SJH. Mitogen activated protein (MAP) kinase signal transduction pathways and novel anti-inflammatory targets. Gut 2003; 52(1): 144-151.

8. Roux PP, Blenis J. ERK and p38MAPK-activated protein kinases: a family of protein kinases with diverse biological functions. Microbiol Mol Biol 2004; 68(2): 320344.

9. Liu J, Lin A. Role of JNK activation in apoptosis: $A$ double-edged sword. Cell Res 2005; 15(1): 36-42.

10. Ono K, Han J. The p38 signal transduction pathway activation and function. Cell Signal 2000; 12(1): 1-13.

11. Pacifico $F$, Leonardi $A$. Role of NF-KB in thyroid cancer. Mol Cell Endocrinol 2010; 321(1): 29-35.

12. Shi Q, Cheng L, Liu Z, Hu K, Ran J, Ge D, Fu J. The p38 MAPK inhibitor SB203580 differentially modulates LPS induced interleukin 6 expression in macrophages. Cent Eur J Immunol 2015; 40(3): 276-282.

13. Korhonen R, Lahti A, Kankaanranta H, Moilanen E. Nitric oxide production and signaling in inflammation. Curr Drug Targets Inflamm Allergy 2005; 4(4): 471-479.

14. Hesslinger $C$, Strub A, Boer R, Ulrich WR, Lehner MD, Braun C. Inhibition of inducible nitric oxide synthase in respiratory diseases. Biochem Soc Trans 2009; 37(4): 886-891.

15. Su XD, Ali I, Arooj $M$, Koh YS, Yang SY, Kim YH. Chemical constituents from Sanguisorba officinalis $L$. and their inhibitory effects on LPS-stimulated proinflammatory cytokine production in bone marrowderived dendritic cells. Arch Pharm Res 2018; 41(5): 497-505.

16. National Research Council (US) Committee for the Update of the Guide for the Care and Use of Laboratory Animals. Guide for the care and use of laboratory animals. 8th edition. Washington (DC): National Academies Press (US); 2011.

17. Ali I, Manzoor Z, Koo JE, Kim JE, Byeon SH, Yoo ES, Kang HK, Hyun JW, Lee NH, Koh YS. 3-Hydroxy-4,7megastigmadien-9-one, isolated from Ulvapertusa, attenuates TLR9-mediated inflammatory response by down-regulating mitogen-activated protein kinase and NF-KB pathways. Pharm Biol 2017; 55(1): 435-440. 
18. Chae D, Manzoor Z, Kim SC, Kim S, Oh TH, Yoo ES, Kang HK, Hyun JW, Lee NH, Ko MH, et al. Apo-9'fucoxanthinone, isolated from Sargassum muticum, inhibits CPG-induced inflammatory response by attenuating the mitogen-activated protein kinase pathway. Mar Drugs 2013; 11(9): 3272-3287.

19. Bao L, Lindgren JU, Meide P, Zhu SW, Ljunggren H-G, Zhu J. The critical role of $I L-12 p 40$ in initiating, enhancing, and perpetuating pathogenic events in murine experimental autoimmune neuritis. Brain Pathol 2006; 12(4): 420-429.

20. Ishii KJ, Koyama S, Nakagawa A, Coban C, Akira S. Host innate immune receptors and beyond: Making sense of microbial infections. Cell Host Microbe 2008; 3(6): 352363.

21. Mclnnes IB, Leung BP, Sturrock RD, Field M, Liew FY. Interleukin-15 mediates $T$ cell-dependent regulation of tumor necrosis factor- $\alpha$ production in rheumatoid arthritis. Nat Med 1997; 3(2): 189-195.

22. Opal SM, DePalo VA. Anti-inflammatory cytokines. Chest 2000; 117(4): 1162-1172.

23. Akira S, Takeda K, Kaisho T. Toll-like receptors: critical proteins linking innate and acquired immunity. Nat Immunol 2001; 2(8): 675-680. 